\title{
Higher education for sustainability - a change of education genre?
}

\author{
Jana Dlouhá, Jiří Dlouhý
}

Envigogika 9 (1) - Reviewed Papers / Recenzované články

Published/ Publikováno 30. 5. 2014

DOI : $10.14712 / 18023061.440$

\begin{abstract}
This paper reflects on the role of universities in social changes, particularly in processes of societal transformation towards sustainable development. It is based on the document Peoples' Sustainability Treaty on Higher Education Towards Sustainable Development, produced for and introduced on the occasion of the Rio+20 Conference in 2012 , which presents a vision for an overall transformation of universities related to the society-wide requirement for sustainable education involving every aspect of higher education institutions (curricula and teaching, campus operations, community engagement, cultural change). Within this framework, the authors demonstrate the main changes currently underway in higher education within six spheres that include: value-based preconditions for action, a holistic approach, knowledge management, an emphasis on learning processes and competencies (the importance of which is growing among education objectives), and methods of evaluating quality of learning process and learning outcomes. They recapitulate the impact of these trends within the Czech education environment and opportunities for future development; they show how real world changes in progress are related to the transformation of both scientific paradigms and education theories. They propose describing this development as a change of education genre, primarily with respect to how knowledge is communicated. They show what new processes in education will gradually have to be taken into account, and offer potential future research topics related to these.
\end{abstract}

\section{Key words:}

Higher education; Education for sustainable development; Curricular transition; Values; Learning process; Competencies; Assessment

\author{
Vzdělávání pro udržitelnost na vysokých školách - jde o změnu \\ vzdělávacího žánru?
}

\begin{abstract}
Abstrakt
Text reflektuje úlohu vysokých škol ve společenských změnách, konkrétně $\checkmark$ procesech transformace společnosti k udržitelnému rozvoji. Vychází z dokumentu Úmluva o vysokoškolském vzdělávání pro udržitelný rozvoj, který vznikl a byl představen u
\end{abstract}


př́ležitosti konference Rio+20 v roce 2012 a který předkládá vizi celkové proměny univerzit související s celospolečenskými požadavky na udržitelné vzdělávání - zahrnuje všechny aspekty života vysokoškolských institucí (výuku, správu, vzdělávací politiku). V tomto rámci autoři ukazují hlavní, v současné době probíhající změny ve vysokoškolském vzdělávání, a to $v$ šesti okruzích, které zahrnují: hodnotové předpoklady akce, holistický přistup, změny v nakládání se znalostmi, důraz na procesy učení a na kompetence (jejichž význam mezi vzdělávacími cíli roste), a způsoby hodnocení kvality procesu a výsledku učení. Rekapitulují dopad těchto trendů v českém vzdělávacím prostředí i možnosti budoucího vývoje; ukazují, jak reálně probíhající změny souvisí s proměnou vědeckých paradigmat i vzdělávacích teorií. Navrhují popsat tento vývoj jako proměnu vzdělávacího žánru, tedy především s ohledem na to, jak jsou poznatky komunikovány, jak se proměňuje způsob jejich přenosu či sdílení ve vzdělávacím procesu. Ukazují, s jakými novými charakteristikami tohoto procesu bude postupně nutno počítat, a nabízejí možná budoucí výzkumná témata s tím související.

\section{Klíčová slova:}

Vysoké školy; Udržitelný rozvoj; Transformace k udržitelnosti; Environmentální hodnoty; Procesy učení; Kompetence; Hodnocení 


\section{I ntroduction}

When representatives of major institutions met at the Earth Summit on Sustainable Development for the third time in June 2012 to discuss options for coordinated remediation of the environment in all its aspects, they faced a relatively hard task: to pick up the threads of two previously ground-breaking conferences (summits on sustainable development were held in Rio 20 years earlier and in Johannesburg 10 years earlier) and present options for further progress. All this was at a time of economic crisis, when interest in such issues generally wanes and, what is more, there has essentially been a shortage of tools for evaluating what has been achieved. The meeting turned out as it had to under these circumstances: the delegates confirmed their (grand) visions and (relatively lesser) commitments from the past, and tried to arouse some hope for the future. A fundamental shift in strategic thinking, as promised by Agenda 21 twenty years before and its Implementation Plan ten years later, failed to take place. As for education, the meeting did confirm its key role in transforming society towards sustainability, but the results of the ambitious plans expressed in Chapter 36 of Agenda 21 from 1992 (UN, 1992) and the UN Decade of Education for Sustainable Education, declared as part of its implementation for the years 2005-2014, were not commented upon. However, something did happen on the occasion of this last, still important meeting in 2012, that is perhaps worth a little more attention than the new official declaration, the incumbency of which is in direct proportion to national policy-makers' willingness to understand and apply the most important principles and tools of sustainable development. Where governments withdrew from making new strategies, an interesting bottom-up initiative appeared: on the eve of the official talks, representatives of civil society (so-called major social groups) designed by themselves 14 treaties concerning issues such as sustainable production and consumption, general responsibility, sustainable economy, etc., including radical ecological democracy and other areas. Some of them are documents that return the discussion to square one, as is the case with the Peoples' Sustainability Treaty on Environmental Education for Sustainable Societies and Global Responsibility, which does not take into account the systemic changes in educational systems, both formal and informal, for which conditions have in the meantime been created world-wide (e.g. by the UN European Economic Commission). In the area of higher education, however, the creators of the Peoples' Sustainability Treaty on Higher Education Towards Sustainable Development (hereinafter, PST) managed rather well to combine previous strategies (and experience with their application at this education level) with expert knowledge of the issues. The resulting document, created under a joint platform of higher education institutions world-wide, which today has more than 80 official partners (Tilbury, 2012), thus demonstrates a whole range of preconditions and options for transformation of the education system and proposes practical steps at the higher education policy level as well as at individual universities themselves.

\section{Peoples' Sustainability Treaty on Higher Education Towards Sustainable Development}

The document, presented on the occasion of the Rio+20 Conference in 2012, follows up not only on all the previous initiatives in the area of higher education (it lists 23 of them since 1990), but also on the results of the research that has evolved at this education level. At a practical level, it presents an overview of methods for "greening" the university as well as the spheres in which this can be achieved. Without dealing with reasons why to do so (adoption of sustainable development strategies in various areas is justified by the necessity for self-preservation or threats to the environment more in countries where cultivation of public interest is not yet commonplace), we will take its basic principles and spheres of "greening" as the foundation for this brief study/analysis. 
According to the PST, "green university" refers to the willingness for change in five areas:

1. university "culture": this aspect includes a combination of teaching, research, university management, and communication with the public;

2. environmentally friendly management of the university campus, including dormitories: energy savings, waste management, ensuring biodiversity, support for fair trade and social enterprise, carbon footprint reduction, and other options for "greening" everyday operations;

3. curriculum changes : they concern mainly inter- and trans-disciplinary approaches and development of critical thinking, and are associated with a holistic or value-oriented view. These changes promote the development of important competencies, chiefly the ability to act in complex situations, the ability to cooperate and maintain dialogue, as well as the art of anticipating the future;

4. community engagement: the systematic traversing of academic boundaries and entry into a dialogue with society (Tilbury, 2004);

5. connecting the system: includes all the above points and creates conditions for their realisation (as a result of education policies at various levels, including quality assessment of universities, their excellence and impact).

All these points are based on the idea of the increased interest of universities in the needs of society, and a willingness to actively promote change in various areas: from university management and operations, the creation of internal strategies and education policy, as well as teaching, its content and methodological issues. Traditionally, universities have represented a model of public institution with a particular social mission and functions, and they have often played the role of a reliable value reference. They anticipate societal "progress" and, as an important social actor, they help the overall stabilisation of society, which is closely related to its sustainable development.

However, promoting the culture of "sustainability" in society is still associated with transformation in various areas, an overall change of values as well as social practice. Promoting such change requires the active approach of all social actors, including the ability to not only learn but also actively intervene in actions. It is this art of transforming theoretical knowledge into socially-oriented action that is typically associated with skills which are not the subject matter of higher education. As mentioned in the PST, implementation of sustainability principles in teaching at the higher education level requires relatively complex change: it involves not only a transformation of the content and form of education from the point of view of different education programmes, but also "great" strategic educational policy goals.

Since the socially-oriented action mentioned above and the abilities that condition it are major transformative factors, this perspective will become one of the cornerstones of the following analysis. Since sustainability principles have not significantly penetrated Czech education policy (certainly not systemically at the higher education level), and the circumstances tend to favour the bottom-up initiatives of university teachers, who often implement them devotedly within their teaching, we will take a closer look below at this challenge in the Czech Republic higher education policy and practice, including changes in communication between scientists or academics and the public (points 3 and 4 of the PST). 


\section{I nnovation in education for sustainable development as a change of education "genre"}

Education for sustainable development is supposed to cultivate understanding of broader societal circumstances even within specialised disciplines. This requires establishing relationships among the environmental, economic and social components in a broader transdisciplinary framework, which is exactly what the sustainable development concept itself is (and which is built upon certain values). From the higher education point of view, the relationship between theory and practice is changing because it latterly includes value-based goals as well ("renewal and remediation of the world"). The knowledge to be acquired by students is thus understood within a new context: not only as a foundation for a knowledge society, a certain "raw material" that can be utilised in any random way to increase prosperity and societal competitiveness, but it becomes an instrument for this "renewal and remediation" which begins to overshadow what originally were purely economically formulated goals (cf. UNESCO, 2005). As will be demonstrated later, the change of overall educational goals in this sustainable framework changes (to a certain extent) the methods for dealing with knowledge and problems: above all, how they are formulated, methodologically managed and communicated. It is with reference to these transformations that we speak of a change of education "genre".

A genre can be defined as the way in which an issue is communicated to a person independently of the content of the issue. Above all, it refers to a settled way of communicating knowledge among those who create and use it in some way. Changes in these communication patterns that concern creation and distribution of new knowledge, which currently occur spontaneously in science, result in methodological changes in teaching, primarily at the university level (Dlouhá et al., 2013b). The following text provides a brief outline of these shifts in the area of university teaching in the context of education for sustainable development both from a theoretical point of view and as a (research) reflection on acquired experience with the practical application of theoretical principles.

The main (new) methodological principles of education for sustainable development, anchored in theory or documents, as well as practical examples of their application, are therefore as follows.

\section{Principle one: change of values}

Education plays not only a significant role in disseminating (communicating) information, but also a formative role: it helps establish ethical norms and hierarchies of life values. Naturally, these change according to social demand: at a time when people began to visibly disrupt the equilibrium of ecological communities, they also realised that human society ought to learn from some natural laws and follow ecological principles, which then penetrated various areas of social life. The word "ecology", denoting the science of relations between an organism and its environment, then became synonymous with a considerate relationship to nature and was supposed to indicate the need to think in terms of relationships. From the mid-1980s onward, it penetrated education too: in the Czech Republic we started using terms like ecological education, too, which was understood to be an appropriate instrument for disseminating these new values (we would refer to them as environmental values today, of course). Back then, universities were already being invited to include ecological aspects in all areas of knowledge, i.e., not only natural science disciplines, which quite naturally study the state of nature, but also technical, economic and social disciplines (Smolíková, 2006). Some of the first initiatives at the higher education level concerned the teaching of non-specialists about environmental matters, including, for example, information on philosophy and the human relationship to the environment, the 
environmental context of the economic and social spheres, as well as practical tools that could be directly used for improving the environment. Later on, this approach (surprisingly) took on a firmer hold at universities and colleges of a technical orientation, which then focused their attention on quite specific, discipline-defined environmental problems, and oriented their education for professionals in this way (Kvasničková, 1990). However, disciplines that prepare professionals comprehensively oriented toward the environmental sphere also appeared at about the same time, such as the specialisation Natural (later Environmental) Protection at the Faculty of Science at Charles University in Prague. Gradually, these rudiments evolved into today's, relatively complex system of higher education in the environmental sphere. In early 2014, it encompassed 40 accredited fields of study focusing on the environment, 59 specialisations with names containing the word "environmental" (a large number of them taught in the English language), 29 specialisations in applied ecology (both technical disciplines and social sciences, 22 in Czech and 7 in English), and 11 specialisations whose name includes an expression related to sustainable development; this totals 141 out of 8888 accredited specialisations at the universities and colleges in the Czech Republic. However, the number of specialisations taught at the faculties of various Czech universities and colleges may be much higher ${ }^{1}$ (AMOS, 2013).

One of the basic features of education for sustainable development is the attention paid to the future; in practice, this means developing the ability to think strategically and make decisions according to democratic principles. A precondition for a person's freedom and responsible conduct is ethics; value-based attitudes enable not only emancipation - the release from existing power structures; ethics is also the pre-requisite for an active approach and becomes the driving force behind all other changes (cf. Dlouhá, 2009c). The value foundations of education are explicitly expressed most notably in teacher education: in the environmental sphere, it fosters values for an environmentally friendly way of life and, in many aspects, thus follows up on original ecological principles. Instead of placing attention on environmental values, an emphasis on behavioural change is sometimes applied because it is easier to formulate measurable goals for environmental education on this basis (for a reflection on the behavioural foundations of this approach, see e.g. Činčera (2009)).

The value foundations of environmental education and education for sustainable development not only develop over time; they are also highly diverse across different cultural and social contexts. This must be regarded as a great asset in this area: it overcomes the risk of ideologisation, fosters critical thinking and the ability to view problems from various perspectives. Of course, ongoing clarification of the basic foundations and approaches to allow their subsequent operationalisation in the form of educational methodologies and tools requires a professional dialogue based on the principle of openness to different opinions (but respecting academic rules). Dialogue of this kind is ongoing also within this journal (see Box 1).

\footnotetext{
${ }^{1}$ A study programme in CR is defined as a self-contained form of tertiary study, typically divided into study specialisations. A study specialisation is a specific focus of the study, accredited upon request by the school. Of course, the same specialisation may be accredited at various faculties or even universities.
} 


\section{Box 1: Over eight years discussion in Envigogika has aimed to clarify various views of and attitudes to} environmental education and education for sustainable development.

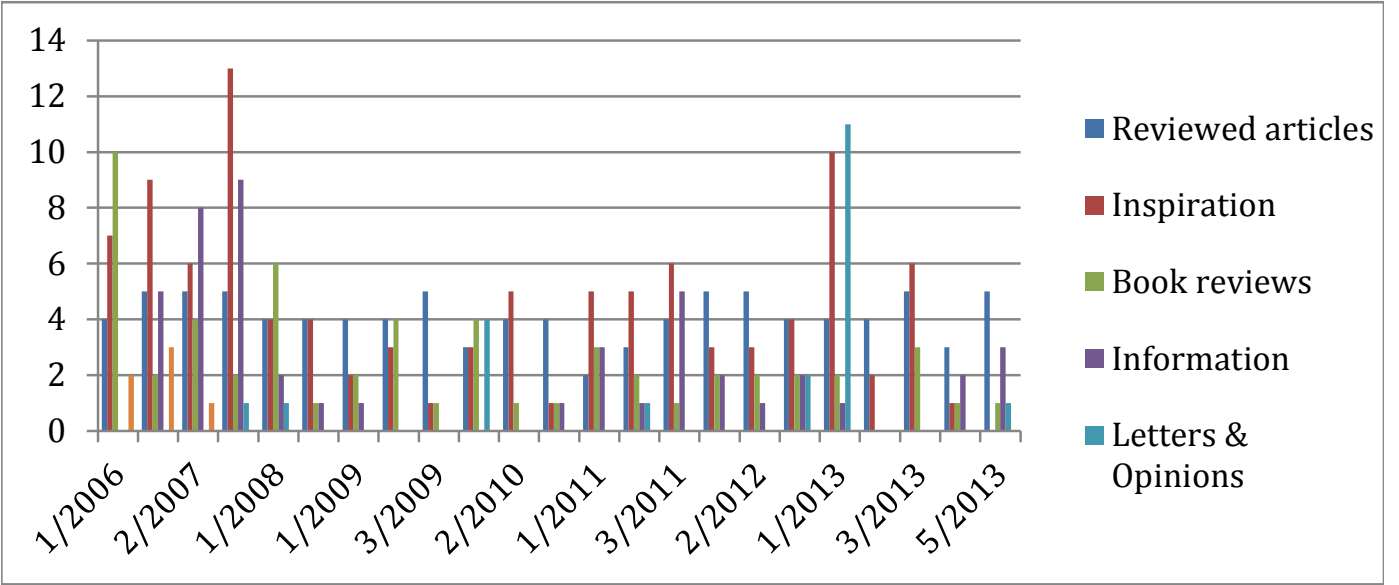

Figure 1: Envigogika (http://www.envigogika.cuni.cz/), reviewed journal for environmental education published by the Charles University Environment Center; number of articles published in the different sections of the magazine since its establishment.

\section{Principle two: holistic approach}

Education is meant to lead to an understanding of the world in its context. John Comenius already knew that the structure of knowledge cannot be built without an overall meaning: “... filling a man with the meaning of the universe, this correspondence between man and existence in its entirety means that man's will will be controlled by an intellectual grasp of what is essential to man, for which he himself is determined." (Comenius, 1948 edition). Specific cognitive principles are derived from this holistic framework, which reflects man's relationship to the world as a whole; this holistic approach is also regarded as one of the foundations of environmental education and education for sustainable development (Dlouhá, 2007a).

However, fulfilling the holistic principle in science and education is in practice quite difficult. The scientific community attempted it during the onset of excessive specialisations of sub-disciplines and a loss of mutual understanding among scientists. Approximately the first half of the $20^{\text {th }}$ century saw the emergence of systems' theories which transform various networks of components into a common denominator (system) and their relationship to functions. Their foundations were originally laid in biology; they were generalised later (Bertalanffy, 1950) and became the basis for other newly emerging disciplines, such as informatics; ecology itself is a systems science. The systems perspective enabled the discovery of similar patterns in different scientific disciplines and was based on this isomorphism that opportunities for generalisation were sought across disciplines, which ushered in numerous attempts at creating interdisciplinary connections across the boundaries of various disciplines. Today, this systems perspective still represents a contrast to the mechanistic understanding of the world: by helping the transfer of notions, laws and models from one context to the other, it makes it possible to look for connections between natural and social phenomena. However, systems sciences have gradually become independent and have ceased to perform this holistic function. They have introduced and formally defined their own object of study, which is the term "system" (Havel, 2005). 
Today, systems thinking is considered to be one of the methodological foundations for seeking practical solutions, and also plays a role in environmental education and education for sustainable development. Nevertheless, numerous authors have criticised the effort to align all (environmental) problems to a common denominator (and thus encompass them within a single all-embracing ecological system (Keulartz, 1998)). Other methods suitable for interdisciplinary work are being sought, namely those that permit diverse approaches to meet research problems and, moreover, enable a broader professional dialogue and involvement of diverse "stakeholders" without eliminating their unique perspectives. The objective is to maintain a debate that does not require a fundamental change of attitudes or views of participants, and permits the coexistence of (conflicting) opinions without necessarily requiring a consensus to be reached ${ }^{2}$.

\section{Holism in practice of higher education}

Consistent application of the holistic approach in higher education in the Czech Republic has led to the establishment of study programmes or modules that included the alignment of diverse specialisations. Nevertheless, they often simply represented multidisciplinary sets of knowledge collected in a very general framework of ecological values and principles. This method of establishing interdisciplinary links has been gradually abandoned: with a few rare exceptions of holistic programs (such as Social and Cultural Ecology taught at Charles University in Prague and Humanist Environmentalistics at Masaryk University in Brno), Czech universities and colleges have over time typically sought a more specific and practical focus within a relatively narrowly defined parent specialisation. The holistic approach is relatively difficult to push through even at faculties of education, although it is closely related to personal development and is an opportunity for cultivating interdisciplinary (and inter-subject) relationships. For holistic approaches to grow under environmentally oriented teaching programmes for future teachers (mostly problem or project-oriented), consistent external stimulation is often needed, for example from nonprofit organisations (Máchal, 2007). Example of good practice see Box 2.

\section{Principle three: knowledge as a basis for decision-making}

Whilst the ethical foundations more or less constituted; conceptual preconditions for a general transition, and a holistic understanding of problems led to the ability to solve them from the point of view of general - not purely professional - objectives, active utilisation of knowledge is now newly emphasised especially in education for sustainable development. Cognitive and social constructivism (cf. Průcha et al., 1995) is regarded as the basis for the ability to apply knowledge in social practice; it is manifested in education as an emphasis on active teaching concepts, experience learning, (self-) reflection, and the social dimension of education. These foundations have an influence on the learning process as such: a critical and creative approach and the possibility of a confrontation of different opinions are

\footnotetext{
${ }^{2}$ For interdisciplinary work, we can create so-called boundary objects, defined by Susan Leigh Star and J ames Griesemer (1989) as follows: they are at the point of intersection of various social worlds, yet they provide each one of them with information; for work with them to achieve coherence across the worlds, they have to be malleable enough (adjust to the needs of various parties), robust enough (enable retention of identity within these differing views), and they should attain different meanings in different social worlds, yet they should be intelligible in more than one of them. These objects can then play the role of a shared object of interest that is accessible to viewing and manipulation from various sides (Keulartz, 2009). In education, the role of such objects should be played by boundary topics, which would be approached based on specific, interdisciplinarily defined rules.
} 
Box 2: A holistic approach applied in tertiary teaching as part of the interdisciplinary subject "Globalisation" has been taught for all faculties at Charles University since 1999. This is an example of diverse discourses meeting around a central, "boundary" topic, contributing different perspectives for a critical understanding of the subject. Various disciplinary experts come together over a common problem, and each explains it from his/her own point of view, creating a dynamic picture of the global process (Dlouhá et al., 2006). An important point is that the students themselves have to build their understanding based on these component inputs: knowledge of this kind differs from a mere set of individual disciplinary views. One of the goals of teaching thus has to be the creation of the student's own opinion and fostering his/her critical perspective on diverse information and attitudes.

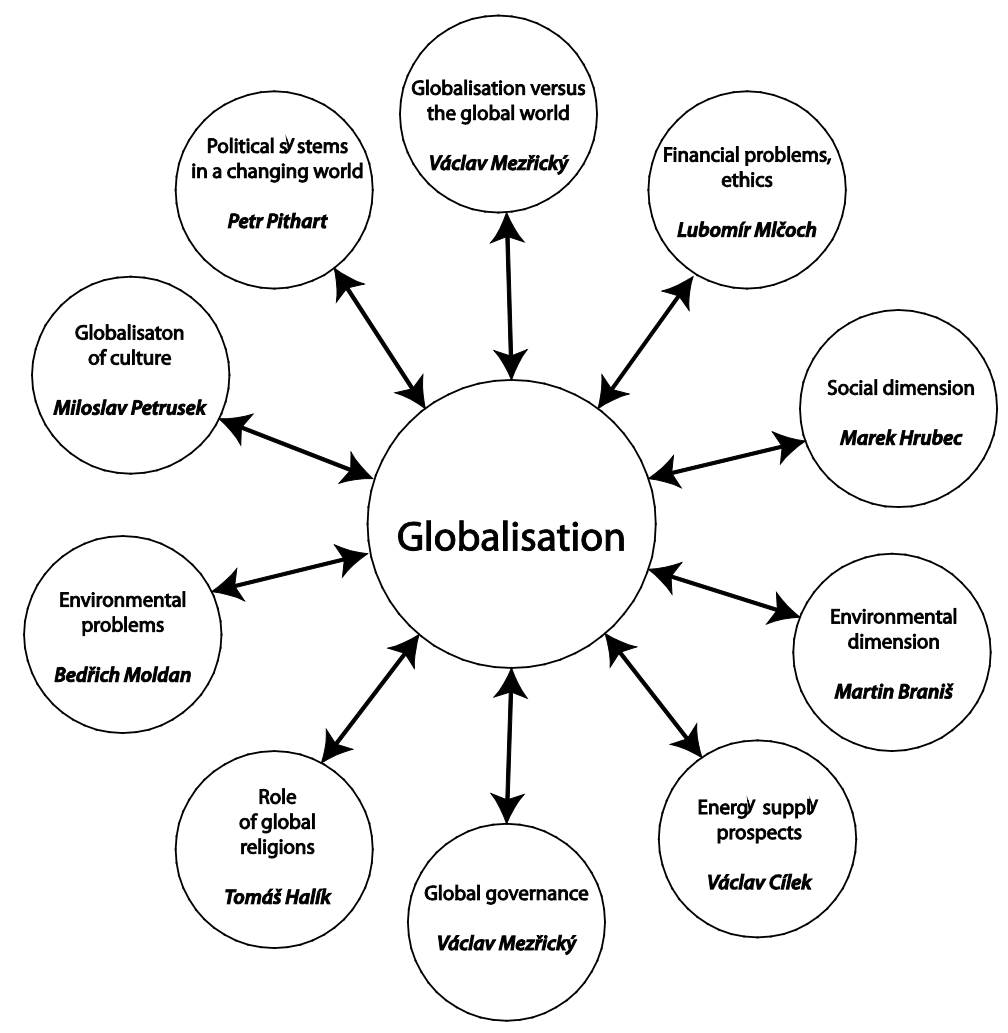

Figure 2: The Globalisation course taught at Charles University in Prague since 1999, organised by CUEC in cooperation with the Faculty of Law; course contents in the summer term of 2010/2011.

emphasised, the role of the student in the (self-)management of the learning process is discussed, and more.

In this learning model, every piece of knowledge gains a new role, thus changing the methods of working with it. Action becomes the focus of attention, and as a consequence, the direction of cognition reverses: not from an internalised piece of knowledge to practice, but from the urgency to take certain steps (for example, for urgent preservation of the environment) to the need to gather relevant information for evidence-based action. This method of working with information involves specific skills which ought to be taught along with the knowledge itself: the focus is not only on the ability to acquire (quality) information but also the ability to assess it critically, use it in argumentation, make it a starting point for research, etc.; above all, to ask questions concerning planned action and then rationalise them with facts. The development of situational understanding is important here; the need to reflect upon not only the action itself but also its preconditions is mentioned (double-loop 
learning; cf. Schön, 1983). Learning processes are at the centre of attention; as a result, this approach also makes specific requirements on teaching and texts utilised as part of it: they are no longer "containers" of knowledge, which only require updating, but rather are used as pointers leading to primary sources, and a source of methodological tools for their use. Reading such texts requires not only a deeper understanding of their content, but also a simultaneous reflection of the basic terms and methods used so as to enable transition of understanding between different discourses ${ }^{3}$.

An entirely specific characteristic of communication in the environmental sphere is the requirement for openness of information sources: the general principles of dealing with information on the environment were formulated in the Aarhus Convention on Access to Information (1998), pursuant to which everyone has the right to information on the environment, and the emphasis is on its active provision, meaning publication in a form that is intelligible and accessible to users (which is mostly via electronic media nowadays). These requirements are associated with the overall concept of information as the basis for democratic decision-making in the area of the environment: information is regarded as a precondition for emancipation of those population groups that are endangered by the state of the environment.

The openness principle is, or should be reflected in the education process, if only because it is a recent general trend that we should be able to utilise for improving the general awareness and deeper understanding of interdisciplinary connections. This openness is gradually penetrating the academic environment, too; here, it concerns primarily the form of publication of study materials, as well as research results (open access sources and publication media are ever more prevalent). However, it also helps the overall change, e.g. in the communication practices between the teacher and the student; it also affects their hierarchical relationships; moreover, it provides the opportunity to broaden the scope of actors involved in interdisciplinary dialogue to other societal stakeholders outside the academic sphere, which is one of the preconditions for fulfilling the social role of universities and colleges (Huisingh, 2006).

\section{Good practice}

The gradually improving accessibility of information to a broader circle of users is related to the development of information and communication technologies (ICT); this process results, among other things, in a gradual professionalisation of lay people, notably non-governmental organisations, and not only in the environmental sphere (Čada and Ptáčková, 2013). In this context, the desirable goals of the education process include primarily the skill of working with different information sources, which involves the ability to find them, as well as critically assess their quality, etc. Such skills should be systematically fostered within academia as part of learning process of academic writing (see Box 3 ).

\footnotetext{
${ }^{3}$ The notion and the method, that is, the way in which one approaches reality, differ in various (disciplinary) discourses: the rules of "utterance" are part of the whole of the utterance (Foucault, 2002). The same word may attain various meanings depending on the context in which it plays a role, and it represents different notions across different disciplines and discourses. Likewise, these differing contexts have different ways of working with notions, argumentation logic, the method of using evidence, etc., even if they describe the same objects or work on the same problem.
} 
Box 3: The electronic environment provides a wide range of opportunities to work with different types of information sources and communication tools. Modern e-learning methods require an active student approach and offer students diverse freedoms (such as work with various study materials); relationships and cooperation among the parties are naturally reinforced and/or communities of interest are founded if an appropriate 'social software' is chosen. The environment tested by the authors in their teaching is an open information space of the Wikipedia type. Teaching based on joint research on a particular theme and academic writing implies the need to overcome disciplinary boundaries; it also enables cooperation on text development by multiple people with different professional backgrounds. An example is the use of the Wikipedia-based environment of VCSEwiki in tertiary teaching, in which students autonomously create case studies describing phenomena or events relevant to the course (for an example of a similar environment, Enviwiki, designed for the courses in Czech, see the Czech version of the article (Dlouhá, 2007b; Zahradník, Pachmanová, 2009).
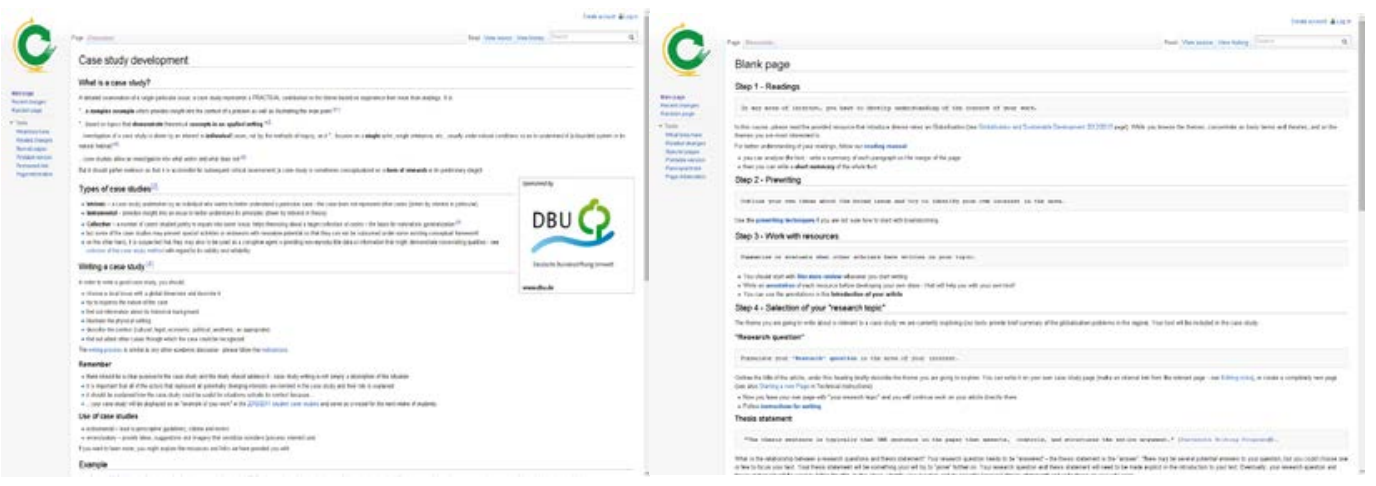

Figure 3. Case study online writing method within VCSEwiki environment for international courses.

\section{Prospects}

Changes in the requirements for the characteristics of teaching texts and generally accepted methods of utilising them have led to the world-wide promotion of so-called Open Education Resources (OER), which promote open and distance learning (Butcher, 2011; Glennie et al., 2012). UNESCO is trying to circulate them world-wide thanks to the ease of sharing materials even with less-developed countries. Nevertheless, a proven result of the use of OER is improving the reputation of universities and attracting new students, the development of individual education, innovation in teaching, as well as the improved financial efficiency of education and improved student preparation (Kapitulčinová et al., 2013).

\section{Principle four: learning processes}

In constructivist learning theories, knowledge is released from the traditional methods of sharing and utilisation: it should be more closely related to the specific learning situation, to which it should adjust itself. It should thus serve as a building stone from which all of knowledge is constructed and which is then specific to both an individual and a (social) context. Knowledge utilisation now is not merely its "application in practice" but rather serves to fulfil the need for responsible and substantiated action, and reflection of its preconditions. The learning process then emphasises the ability to create one's own meanings and understanding, which in unclear situations especially enables the learner to ask questions and enter into a dialogue with other actors. From this point of view, the attainment of a certain amount of knowledge ceases to be the main objective and criterion 
of educational success. Teaching in general, and particularly in education for sustainable development, is then associated with new required learning outcomes: the emphasis is on relationships, processes and interactions, the ability to realise the foundations of one's own thoughts and concepts. Constructivist theories (based on education psychology and pedagogy elaborated in classics by John Dewey, Maria Montessori, Lev Vygotsky, Jean Piaget, Jerome Bruner and others) have turned teachers' attention to learning processes because they form the ability to understand and create cognitive situations, and work with knowledge within them.

As has been proven, external factors have a complex influence on learning processes: the teaching environment, the teaching method applied, the load, the quality of interaction with the teachers, and other teaching/learning circumstances. From the individual's point of view, their learning processes are influenced mainly by his/her approaches to studying, defined as combinations of motives, individual preferences, ways of perceiving the environment, and chosen strategies (Entwistle et al., 2000; Duff, 2004; ETL, 2013). A deep approach to study has thus been defined which is a necessary precondition for the development of desirable skills and competencies, in contrast to the surface approach and other categories. An analysis of study approaches has proven that they are closely linked to the context and environment in which learning processes take place (Duff, 2003); adjustments to the environment can affect these processes, which are then manifested in many aspects of learning up to the students' resulting success in relation to the set educational goals (cf. Dlouhá et al., 2011a).

Learning processes significant from the point of view of sustainable development teaching include so-called social learning processes. The basis of this concept is the idea that people do not learn only autonomously (totally individually) but also to a great extent under the influence of their position within the social context. Learning is then regarded as an "integral part of generative social practice in the world of experience" (Cobb a Bowers, 1999) - it takes place within mutually beneficial interactions among social actors. Social learning is then defined as a social process whose four basic elements (principles) are: action, cooperation, reflection and communication (Wals, 2007; UN ECE, 2009). Put simply, it means that learning processes take place as part of social relationships and practical cooperation, where actors discuss, influence one another and search for new solutions which require agreement in conflicting situations. This opens up new opportunities for joint problem-solving, cultivates more general opinions and views, and changes or empowers the roles of the different actors in the dialogue (See Box 4).

Box 4: Practical applications of social learning consist of the cooperation of universities with regional actors. This is connected to the reinforcement of the role of tertiary education institutions in regional development: universities are regarded as important actors whose authority may support (for instance) sustainable development processes. The principle of partnership and cooperation among different actors, in which new, sustainable solutions are sought and interaction and mutual influencing take place, is included in the programme of the UN Decade of Education for Sustainable Development: it has been embodied in regional associations of universities with other partners (known as Regional Centres of Expertise, RCE), considered to be a kind of incubator for sustainable development initiatives (Zilahy and Huisingh, 2009). There are 160 such Centres around the world at present which are networks in order to exchange their experience (Mochizuki and Fadeeva, 2008; UNI IAS, 2013). 


\section{Future potential}

Analysis and thorough reflection of the interactions of the actors involved in the social dialogue then makes it possible to promote these social learning processes in societal practice or include them in teaching, particularly at the higher education level (Dlouhá et al., 2013c). In general, social learning might be of importance primarily for lifelong learning, characterised by a natural connection between theory and practice, and mutual interconnections within professional knowledge and the need to apply it (Dlouhá et al., 2013d). If these processes were better understood and if adequate tools for "teaching" them were created, we would have a new methodological instrument for developing democratic dialogue between professionals and the lay public. In order to acquire the necessary feedback, sets of quality indicators can be made for these social learning processes which reflect the most important principles of social learning (the indicators have to be designed with respect to predefined teaching/learning goals; see Box 5 for indicators designed for monitoring dialogue among regional development actors, including universities and colleges).

Box 5: Indicators of social learning: proposal for main categories. Indicators have been designed for describing the processes of (social) learning in regional cooperation networks on sustainable development and are below categorised into groups based on the most important characteristics of social learning (source: Dlouhá et al., 2013c).

\begin{tabular}{|l|l|}
\hline Elements of learning process & I ndicators \\
\hline Cooperation & Number of involved stakeholders \\
\cline { 2 - 2 } & Number of different types of institutions involved \\
\hline \multirow{5}{*}{ Learning } & Number of target groups \\
\cline { 2 - 2 } online) - Optional & Involvement of target groups (scale) \\
\cline { 2 - 2 } & Number of learners \\
\cline { 2 - 2 } & Number of learning approaches \\
\cline { 2 - 2 } & Number of different types of learning interactions \\
\cline { 2 - 2 } & Innovative aspects of learning (scale) \\
\hline Reflection - Optional & Online learning activities (scale) \\
\cline { 2 - 3 } & Purpose of online learning activities (scale) \\
\hline Action & Number of research methods \\
\cline { 2 - 3 } & Description of research benefits (scale) \\
\hline & Impact description: Social (scale) \\
\cline { 2 - 3 } & Impact description: Environmental (scale) \\
\cline { 2 - 3 } & Impact description: Economic (scale) \\
\hline
\end{tabular}

Table 1. Indicators of social learning: proposal for main categories. (source: Dlouhá et al., 2013c)

\section{Principle five: overall change of education goals: competencies}

Education goals that involve all the aforementioned principles are so-called competencies which are regarded as both a result and precondition for constructivist-based active education. Besides traditional knowledge, competencies play an increasingly 
important role, chiefly where an individual has to be led towards conscious decision-making at both the individual and social levels.

The competency concept includes a set of knowledge and attitudes and combinations thereof; Franz Weinert (2001) defined them as a "system of abilities, skills and knowledge that are required to achieve a certain goal". Their general characteristic is that they are related to a certain activity and its performance (Schneckenberg and Wildt, 2006), and fulfil the requirements of a professional or social role. They are always manifested in a certain context, which also has to be taken into account in teaching (Dlouhá, 2009a, b; Dlouhá et al., 2013a). Competencies include skills required for regulating the learning process, such as comprehensive thinking (understanding of interdisciplinary connections), the ability to view information sources and the environment critically, and other abilities related to an active approach (the ability to solve problems and make decisions, creativity, inquisitiveness, interest in ethical issues, etc.). Competencies as educational goals and outcomes are being discussed more and more within the context of environmental education and education for sustainable development (Wiek et al., 2011).

\section{Good practice examples}

Specific competencies should also be cultivated as a part of academic work: a typical example are skills associated with understanding and creating texts. From the point of view of education for sustainable development, one also has to be able to create and interpret a text as a "boundary object" for discussion from various approaches and perspectives. The art of reading a text, using it as a basis for argument, and quoting and producing one's own text is thus supplemented by other skills, such as co-creating, sharing, being able to describe the terminological and methodological foundations of the text, and then discuss these principles embedded in the message from various viewpoints. When working with a text as with a boundary object, we need to systematically provide room for views from these different perspectives. Such "boundary" texts, over which representatives of diverse (often controversial) opinions can meet, may be, for example, case studies of regional sustainable development problems: in addition to an objective description of the situation, they may also contain a subjective picture of stakeholder interests, which makes it possible to view the case from multiple perspectives. The case study text should then describe the situation in a balanced manner (taking into account various attitudes and views); in teaching, it may serve to develop a discussion in which differing opinions are refined (for more on case studies, cf. Dlouhá et al., 2012a; Dlouhá, 2013f). Case study writing method see Box 6.

\section{Principle six: change of the evaluation method}

The transformative tendencies in the curricular area also imply the necessity to change evaluation at all levels: in relation to individual students, the course, the education programme, the institution... Here, we refer to various changes in the evaluation method at the level of a course, although they ultimately imply a redefinition of teaching quality as such.

Generally speaking, in education all the factors that play a role have to be aligned: not only education goals and content, but also the environment, required tasks, roles of teachers and students, as well as evaluation methods. That is relatively difficult particularly with regard to evaluation, and so it is still common - even at the higher education level - to assess "what is easy to measure rather than what matters"; tests and hand-in seminar papers are a commonly applied method (Reeves, 2006). However, modern methods are not based on assessment against external standards but instead use processes of self- 
Box 6: Case studies can be used in teaching as a "boundary object" for discussing problems of sustainable development (demonstrated by the chosen case) as well as a topic for joint student work (tasked to describe the case, for example from the point of view of actors involved).
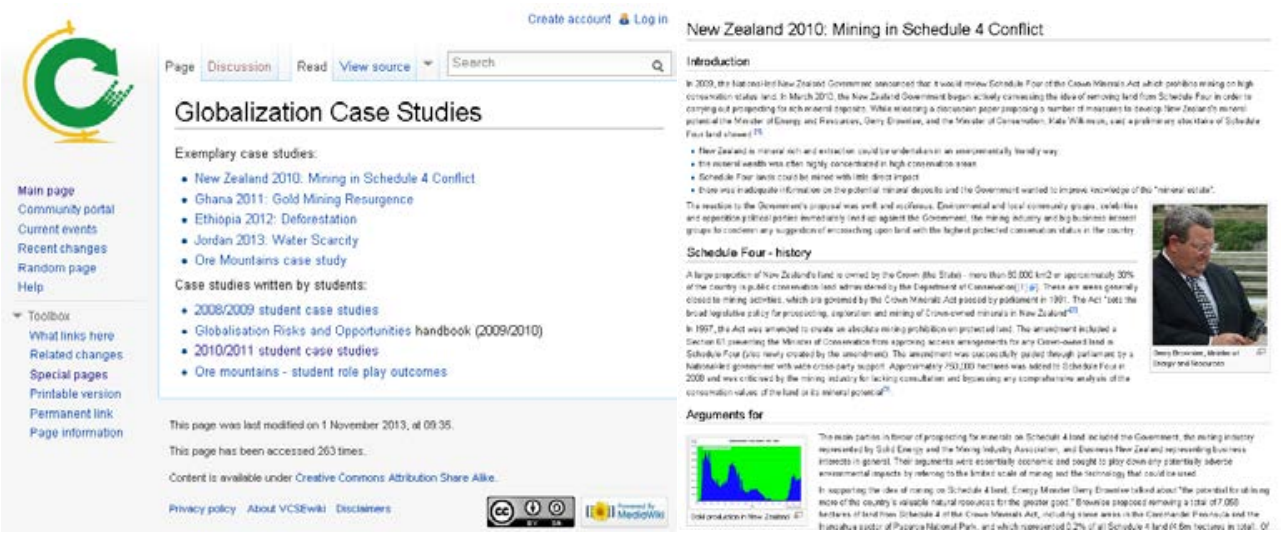

Figure 4. Case studies developed within VCSEwiki environment for international courses.

assessment and mutual evaluation, which involves students who thus also acquire experience with generally applicable requirements (Sadler, 2005). So called rubrics are one of the suitable tools: they make it possible to evaluate the quality of students' independent work (such as the texts that they write as seminar papers) and competencies necessary for completion of the task comprehensively, from various points of view (Dlouhá, 2013e).

From the range of tools for assessing the quality of learning processes, we have selected the evaluation of student approaches to study: it provides a picture of an important aspect of the education process which has so far been paid little attention, and also provides feedback on teaching environment factors (e.g. whether it is inspiring or boring). The method is based on an understanding of the extent to which students apply the deep/surface approach to study. The deep approach to study can be described as "searching for the essence of the problem being studied, establishment of connections with other experience, and critical assessment of various opinions". Students who apply this deep approach in their study are truly interested in their object of study, it entertains them and it is their goal to understand it. In contrast, the surface approach can be characterised as rote learning (by heart), memorising of facts without additional connections. "Surface" students perceive tasks as an external burden and study without intrinsic motivation. They typically regard parts of the subject being studied as separate entities and fail to combine the different topics into a coherent whole (Duff, 2004). This evaluation tool is particularly suitable for assessing interdisciplinary, actively focused teaching, where specific (disciplinary) knowledge is not the primary education goal (which is very often the case in education for sustainable development) (See Box 7).

\section{Discussion}

In all six examples of "innovation" in education for sustainable development presented above (which are, however, based on fundamental but often forgotten education principles), we will now follow the "action" dimension of the educational goals and processes: it will form the basis for the following brief analysis. 


\section{Values as a precondition for action}

Values may influence conscious decision-making and are thus a precondition for practical action aimed at promoting (environmental) public interest as well as sustainable development strategies. We have seen that these values have transformed historically from an ecological/environmental attitude (taking an interest in the environment) to values of sustainability oriented toward the future. This is related to a change in the goals of higher education teaching, embodied for example in the concept of study programmes. Values are contained implicitly in the selection of study themes or objects in teaching activities themselves: courses, topics of papers, etc. We have provided an example of a global issues interdisciplinary course, where we have worked with the diverse disciplinary foundations and value systems of the different actors involved in globalisation in both the course design and content.

These values which are rather implicit in non-humanity disciplines are often included in humanity disciplines explicitly as themes related to environmental ethics or philosophy; this is also true of teacher training disciplines which embody education towards an environmentally or sustainably grounded attitude or opinion. Pedagogic psychology sometimes works more with value manifestations such as environmentally friendly behaviour, which then represent the focus of the teaching activities (Krajhanzl, 2009). The reason here is that the results of this educational work are easier to measure, and because programmes can be designed specifically to achieve them (Činčera, 2010).

Box 7. An example of evaluating students' approach to learning is the method that makes use of the Revised Approaches to Studying Inventory (Entwistle, 2000; Richardson, 2005). This is a standardised procedure based on a questionnaire survey, which has been verified on a large number of students and is thus usable also for smaller sets of student respondents at the end of a teaching module. The method is based on the students' perceptions of the learning process; the answers are evaluated against an experimentally drawn scale with a description of the categories. An extended version of the questionnaire survey also gathers responses to questions on the adequacy and nature of requirements made on the students, requirements on their autonomy, work load, appropriateness of the methodological tools used to support teamwork, the degree of satisfaction with one's own involvement, etc. This qualitative feedback is suitable for tertiary teaching focusing on fostering desirable learning processes and the development of relevant competencies. For the abridged version of the questionnaire and survey results from a pilot international course of globalisation in 2010, see the table below.

Table 2. Results obtained in final standardised Revised Approaches to Learning and Studying Inventory (RASI) questionnaire: DA = Deep approach, MS = Monitoring studying, $0 \mathrm{~S}=$ Organised studying and effort management, $S A$ = Surface approach. Five-point scale, 1 = strongly disagree, $5=$ strongly agree.

(Source: Dlouhá et al., 2011a, c).

Colour scale used in all following tables: 5-point Likert scale (from Strongly disagree = 1 point to Strongly agree $=5$ points)

\begin{tabular}{|l|l|l|l|l|l|l|l|l|}
\hline 1 & 1.5 & 2 & 2.5 & 3 & 3.5 & 4 & 4.5 & 5
\end{tabular}




\section{Box 7 cont.}

\begin{tabular}{|c|c|c|}
\hline \multirow{2}{*}{$\begin{array}{l}\text { Demonstration of the } \\
\text { learning approach }\end{array}$} & $\begin{array}{l}\text { Data 2009/2010 } \\
\text { (12 students) }\end{array}$ & \multirow{2}{*}{$\begin{array}{l}\text { Indicate to what extent you agree with the following } \\
\text { statement... }\end{array}$} \\
\hline & median & \\
\hline $\begin{array}{l}\text { DA: Intention to understand } \\
\text { for oneself }\end{array}$ & 4 & $\begin{array}{l}\text { I have usually tried to understand for myself the } \\
\text { meaning of what we had to learn }\end{array}$ \\
\hline $\begin{array}{l}\text { DA: Intention to understand } \\
\text { for oneself }\end{array}$ & 4 & $\begin{array}{l}\text { In reading for this course, I've tried to find out for } \\
\text { myself exactly what the author means }\end{array}$ \\
\hline $\begin{array}{l}\text { DA: Relating ideas } \\
\text { (including constructivist } \\
\text { learning) }\end{array}$ & 4 & $\begin{array}{l}\text { In making sense of new ideas, I have often related } \\
\text { them to practical or real life contexts }\end{array}$ \\
\hline $\begin{array}{l}\text { DA: Relating ideas } \\
\text { (including constructivist } \\
\text { learning) }\end{array}$ & 3.5 & $\begin{array}{l}\text { Ideas I've come across in my academic reading } \\
\text { often set me off on long chains of thought }\end{array}$ \\
\hline DA: Use of evidence & 4 & $\begin{array}{l}\text { I've looked at evidence carefully to reach my own } \\
\text { conclusion about what I'm studying }\end{array}$ \\
\hline DA: Use of evidence & 4.5 & $\begin{array}{l}\text { It has been important for me to follow the argument, } \\
\text { or to see the reasons behind things }\end{array}$ \\
\hline $\begin{array}{l}\text { MS: Monitoring generic } \\
\text { skills }\end{array}$ & 4 & $\begin{array}{l}\text { When I've been communicating ideas, I've thought } \\
\text { over how well I've got my points across (so that } \\
\text { others understand) }\end{array}$ \\
\hline $\begin{array}{l}\text { MS: Monitoring generic } \\
\text { skills }\end{array}$ & 3 & $\begin{array}{l}\text { I've tried to find better ways of tracking down } \\
\text { relevant information on this subject }\end{array}$ \\
\hline $\begin{array}{l}\text { MS: Monitoring } \\
\text { understanding }\end{array}$ & 4 & $\begin{array}{l}\text { I have been revising the work I've done to check my } \\
\text { reasoning and see that it makes sense }\end{array}$ \\
\hline $\begin{array}{l}\text { MS: Monitoring } \\
\text { understanding }\end{array}$ & 4 & $\begin{array}{l}\text { If I've not understood things well enough when } \\
\text { studying, I've tried a different approach }\end{array}$ \\
\hline OS: Concentration & 4 & $\begin{array}{l}\text { Concentration has not usually been a problem for } \\
\text { me, unless I've been really tired }\end{array}$ \\
\hline OS: Effort & 5 & I have generally put a lot of effort into my studying \\
\hline OS: Organised studying & 4 & $\begin{array}{l}\text { On the whole, I've been quite systematic and } \\
\text { organized in my studying }\end{array}$ \\
\hline OS: Time management & 4 & $\begin{array}{l}\text { I've organized my study time carefully to make the } \\
\text { best use of it }\end{array}$ \\
\hline SA: Fragmented knowledge & 2 & $\begin{array}{l}\text { Much of what I've learned seems no more than lots } \\
\text { of unrelated bits and pieces in my mind }\end{array}$ \\
\hline $\begin{array}{l}\text { SA: Memorizing without } \\
\text { understanding }\end{array}$ & 2.5 & $\begin{array}{l}\text { I've often had trouble in making sense of the things } \\
\text { I have to remember }\end{array}$ \\
\hline SA: Unreflective studying & 2 & $\begin{array}{l}\text { I've just been going through the motions of studying } \\
\text { without seeing where I'm going }\end{array}$ \\
\hline SA: Unthinking acceptance & 2 & $\begin{array}{l}\text { I've tended to take as guaranteed what we've been } \\
\text { taught without questioning it much }\end{array}$ \\
\hline
\end{tabular}


These attempts are based on research results achieved particularly in the USA; on the other hand, the assumption that "there is a simple relationship between knowledge, awareness, attitude, and environmental behaviour" is harshly criticized in the European cultural context (Wals et al., 2014). According to these authors, "more attention is now being given to an understanding of the learning processes and the capacities of individuals and communities needed to resolve complex socioecological issues". Behavioral changes thus cannot be widely accepted as the primary educational goal (cf. Dlouhá, 2009a, b).

\section{Holistic approach}

This perspective is important for understanding the meaning of what has been learned and man's position in this knowledge of the world; this is a reason for him or her to engage in remedying it. A holistic concept of the world and its components, described in a disciplinary way or otherwise, is the basis of educational work in general; at the expert level, it is expressed as an effort to establish an inter- or trans-disciplinary science with a practical impact. Since expert knowledge is highly specialised these days and cannot be integrated on a single (philosophical) basis (such attempts are viewed as deeply essentialistic; see Keulartz (1998, 2009)), the holistic approach involves development of new methods and tools for dialogue across disciplinary boundaries. The creation of "boundary objects" over which representatives of not only various disciplines but also the non-academic sphere can come together, can serve in this respect for finding emergent solutions (Dlouhá, 2012b).

\section{Changes in knowledge communication and management}

In accordance with constructivist foundations, an overall democratisation of the teaching/learning environment occurs which is related to the transformation of the roles of actors in the process of education and which leads to the greater openness of the learning environment. These changes are also reflected in changes to the information environment and the academic text itself. Moreover, new genres appear with varying professional quality, when highly specialised information is simplified to various degrees and secondary sources created (Wikipedia style), or when "digests" from current research reports are summarized and expert papers are processed into overviews for policy-makers (cf., e.g., UNESCOSCOPE-UNEP (2011) and UNEP (2012)). In sustainable development education, we need to develop awareness of the discursive nature of language (discipline) and cultivate the art of "translation" among these different languages, professional approaches and terminologies.

In addition, we need to develop skills to communicate research results to the public or to formulate them so that they provide evidence for political "action". This is related, among others, to the nature and evolution of the information environment, its openness, and the possibility of accessing information of varying types (and qualities). In this area, the requirements of environmental disciplines are in rare alignment with the overall trends in the evolution of information and communication technologies.

In the context of sustainable development, knowledge is to be utilised as the foundation for decision-making processes at various levels, and a quality criterion is (among others) the success of the action based on it: cognition should have a social impact. This is another attribute of the transformation of the professional genre in both science and education that tries to fulfil positive societal goals in the area of sustainable development (cf. Dlouhá, 2013a).

\section{Learning processes}

Learning processes are at the centre of attention of (tertiary) pedagogy, especially because they represent appropriate educational goals (in the constructivist sense). This 
concept can be applied chiefly wherever so-called dynamic qualities of learning are stressed, and where active and participatory approaches are developed. Dynamic qualities of learning can be seen as the opposite to its "static" qualities, which are more mechanical, and regard teaching and learning as the mere transfer of information, and students as its passive recipients. The theoretical basis of a dynamic learning culture (as an alternative to a static culture of teaching/learning and technical rationality) had already been formulated by Schön in 1983. In his opinion, cognition is directly associated with (reflection of) knowledge in action: this then enables constant adjustment of cognitive processes to a particular situation (according to the circumstances of action). Action takes place "in a spiral process of reflection, action, and new reflection", and the main concern is an overall understanding of the situation and the ability to then change it. In practice, the relationship and roles of the actors in the learning process also change in such a dynamic setting: the interaction among students and teachers can be described as the mutual influencing and joint creation of situational understanding (Schön, 1983). Attention paid to learning processes can thus contribute to a deeply fundamental change in the education environment and culture of education.

\section{Competencies as the education goal}

Competencies are generally considered to be a significant education goal; they are defined, for instance, as systems thinking, future visioning and strategic skills, critical perspective, and problem-solving ability. At the practical level, the emphasis is on the autonomous attitude of both the teacher and the student in this context; it is important to be able to assess various viewpoints and attitudes impartially; communication skills play an important role. The perceived importance of competencies results in a deeper change, which can be characterised as a shift in the overall orientation of the education situation from a purely application-based (adopt and apply), which leads to mere replication and creation of petrified mental structures, to an action-oriented learning environment (Štech, 1999). Education for sustainable development then often applies the model of so-called action competencies, which embraces all the cognitive, motivational and social preconditions for successful learning and effective action (Allen et al., 2005).

Competencies include all the principles that we mentioned above (and examined in the six examples), and we express them as concrete education goals which include both technical capability and the ethical dimension (Sterling, 1996) and are formulated actionwise (Anderson and Krathwohl, 2001). These competencies can be regarded as suitable education goals in education for sustainable development realised by the United Nations Economic Commission for Europe. Its experts developed these competencies for education for sustainable development as desirable educator skills and abilities at all levels of education (UN ECE, 2011). ESD competencies are clustered in learning domains based on the concept of four pillars of education by Delors (1997): learning to know, learning to act, learning to be, learning to live together. The UN ECE document divides each of these domains into three areas: holistic approach, future visioning, and achieving transformation. This matrix then describes the most important skills desirable from the point of view of education for sustainable development: what teachers should pass on to their pupils and students along with knowledge itself (UN ECE, 2013).

\section{Quality assessment}

A general shift is occurring in the evaluation of education goals: instead of mere attainment and subsequent application of knowledge (facts, processes and concepts), creative and metacognitive skills and the ability to react on a situation are increasingly regarded as the highest degree of the cognitive process (cf. taxonomy of educational goals according to Anderson and Krathwohl (2001)). When evaluating goals in education for 
sustainable development, this "dynamic" key is also followed: emphasis is placed on cognitive processes, notably active work with information, decision-making capability, and practical action competencies. The results of the education process, traditionally categorised as knowledge, skills and attitudes, are assessed in a more balanced way, often with an emphasis on the affective component; relevant evaluation tools are developed for that.

Learning processes are a precondition for the successful achievement of education goals defined in this way; they can be evaluated on a subjective basis using questionnaire surveys examining students' perception. Based on the results obtained, we can perform an evaluation of approaches to studying and consequently design the extent and nature of requirements made on students, the level of their autonomy, and the amount of knowledge required, or plan teamwork (Dlouhá et al., 2011b). Such evaluation can serve not only to reflect students' individual interest and progress in the area in question, but also to identify their needs and opportunities and to adjust the teaching environment. It is used mainly when introducing various innovations in teaching and it serves for formative evaluation purposes; broader application of these evaluation tools would result in systemic changes in educational assessment at different levels, including the tertiary education system (Daniš, 2013).

\section{Related change of scientific paradigms}

The engagement of science with society is increasingly becoming a topic in environmental disciplines and sustainability sciences. This sustainability framework affects scientific work and its outcomes and has an impact on the transformations science as such: new scientific "paradigms" emerge with various labels such as finalisation science (Böhme et al., 1983), postnormal science (Funtowicz and Ravetz, 1993), Mode 2 knowledge production (Gibbons et al., 1994), innovation systems (Edquist, 1997), post-academic science (Ziman, 2000), "triple helix" model (Etzkowitz and Leydesdorff, 1998), and others (see Hessels and Van Lente, 2008). Under these new concepts, science is also supposed to help achieve goals in the social sphere, for instance by providing necessary data and evidence for decision-making processes. Based on these changes the term socially robust knowledge is formulated, embracing the new approaches and methods at the boundaries of science and politics (Adomßent, 2013) (see Box 8).

The new role of science implies changes mainly in communication practices: for example, additional actors are included in professional dialogue where it is desirable to take into account their opinions (this phenomenon as part the peer review process, extending the circle of reviewers of a scientific result, is described by Funtowicz and Ravetz $(1993,2002))$. Expert information now performs a role not only in the academic discourse (in scientific communication channels) but also in the political discourse (responsible, evidence-based decision-making can be founded on scientific conclusions). As a consequence of this, criteria quality for scientific results and (scientific) knowledge production andreproduction change as well. New scientific genres are created: methodology is one example of such a new and emerging genre at the border between science and politics, performing functions (and appreciated) in both the spheres. It is a tried-and-tested procedure for applying expertise in practice, such as the use of indicators for decision-making in various areas (Rode and Michelsen, 2008). 
On the whole, the role of science shifts from its highly emphasised economic function to the social and political sphere; in our case, scientists are actively advocating sustainable development in various areas ${ }^{4}$.

Box 8. New scientific methods emerging at the border between science and politics (e.g., method of indicators use)).

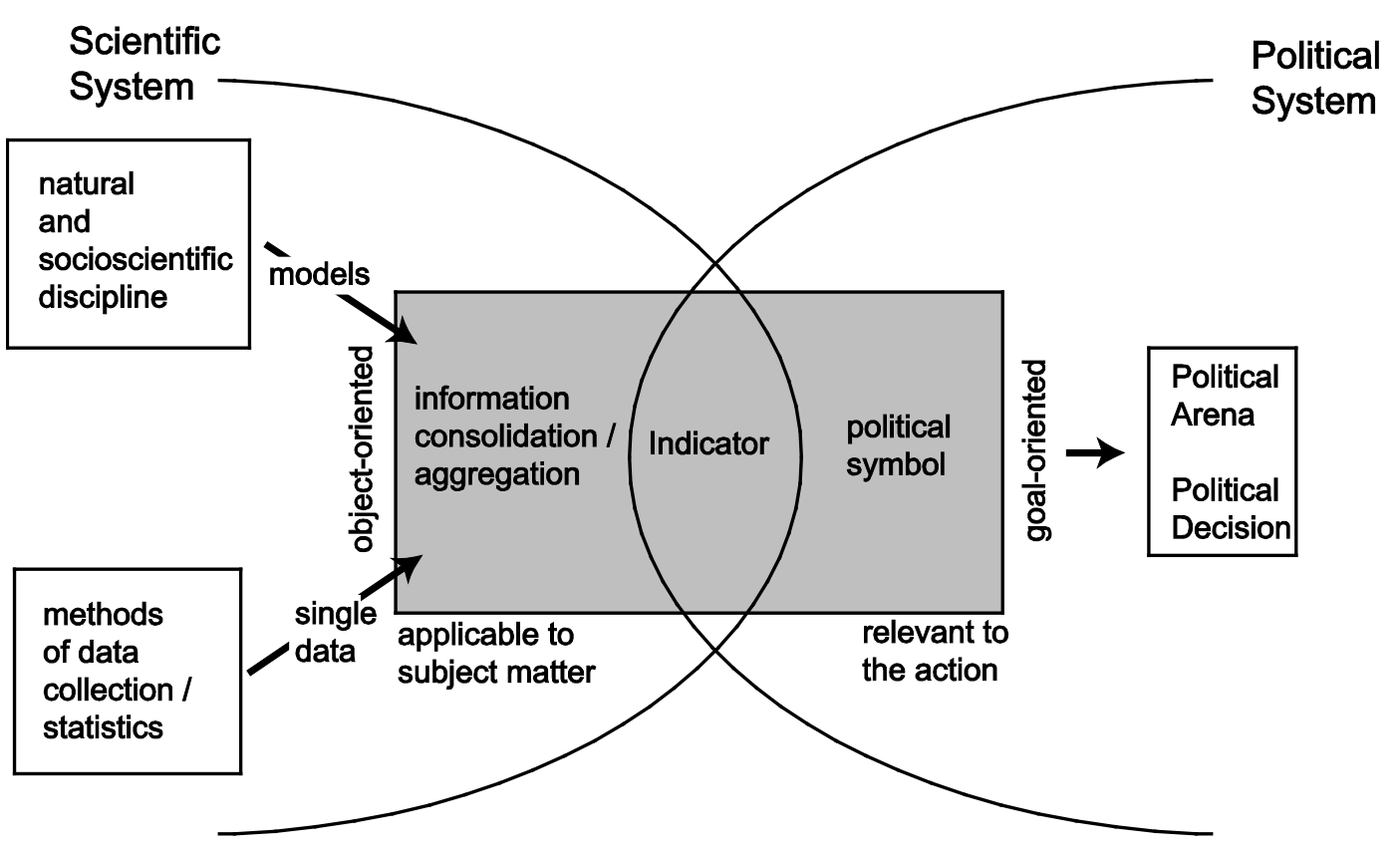

Figure 5. Science-policy interface (source: Adomßent, 2013

\section{Conclusions: transformation of education genre}

The ongoing change in the area of scientific research should not be labeled a "paradigm" change yet. But there is growing evidence that knowledge is generated under new circumstances and with different objectives; the way in which it is communicated, to whom and how it is transferred, is also changing. We can infer that new scientific genres are beginning to emerge under the sustainability framework and elsewhere (such as methodology), and education genres are consequently being independently transformed, and. Knowledge plays a different role, no longer in purely theoretical communication, and not purely as a factor in economic and technical progress (as the basis of a prosperous knowledge society), but also in the context of "remedying the world" with an aim of preventing its devastation (cf. Dlouhá et al., 2013a). The "transfer" of knowledge within education takes on new paths and processes with the following characteristics:

\footnotetext{
${ }^{4}$ It should be noted here that politics in this context does not mean a struggle for voters (and their ideological manipulation), but the ability, at the individual level, to step out of the circle of one's own private interest and take an interest in public matters; at the social level, it refers to reasonable management of public matters for the general good using available resources (including science).
} 
- the action principle - the point of the message is not only knowledge as such, but also the action based on it or that makes use of it;

- the learning process is often more important than its outcome: existing learning about action or for action ought to be complemented with learning in action;

- in action (one of the foundations of the learning process) not only understanding of a problem is developed, but it also situational understanding needs to be fostered. Knowledge in the context of a situation acquires specific characteristics (its genesis, role and effect are associated with the context); therefore, we need to understand the situation in which it plays a role as well;

- reflection plays a role in learning within the action; not only the progress of the action and the adequacy of tools for its successful accomplishment are reflected, but the theoretical foundations and practical preconditions of the action also need to be reconsidered: this is learning with double feedback (Schön, 1983);

- the situation and the action itself are characterised by a high degree of unpredictability which assists in asking questions as part of the learning process and also contributes to the change of the teacher and student roles and relationships: they now "row in the same boat", together exposed to the uncertainties of learning;

- new knowledge is also generated as a result of interaction, where communication (between teachers and students) is not one-way; knowledge is then of an emergent nature: it appears as a consequence of dialogue; this is connected with creativity and innovative thinking;

- information is still the foundation of knowledge, but the way it is acquired and from where change radically: information itself is omnipresent, but the information environment is very ambiguous, and the process of learning has to be navigated by certain values; they become the content of the knowledge along with the information.

Under these circumstances, we can try to express the newly emerging genre at the divide between education and politics (analogously to the newly emerging scientific genre) in the following way, for example (Box 9).

Competencies for action are seen here in the sector including education as well as politics; however, they do not mean just the ability to become engaged, which can be achieved by some kind of "citizenship education" at the higher educational levels. Competencies also mean the ability to work with data and information at the divide between science and politics, and to understand or create methodological tools for mutual understanding of these spheres (such as indicators). Such competencies are the foundation of responsible and substantiated - evidence-based - decision-making.

The transformation of the education genre is also manifested in the education "text" itself (here, text refers to the the teaching materials as such, but also has a broader meaning - it includes teaching modules or other education activity) and means a change of its form and purpose, i.e., why and for whom has it been "written". This "text" (education module, etc.) is thus still based on verified and scientifically established information, but it emphasises the diverse methods of working with it. The possibility to choose from multiple ways of generating and utilising knowledge then has relatively far-reaching implications for how to design teaching modules, what to include in them, whom to involve and how, etc. 
Box 9. New education goals that can be defined at the education and politics interface: so-called competencies for action, including the ability to maintain a dialogue and enter into relationships among various social actors.

\section{Education}

Policy

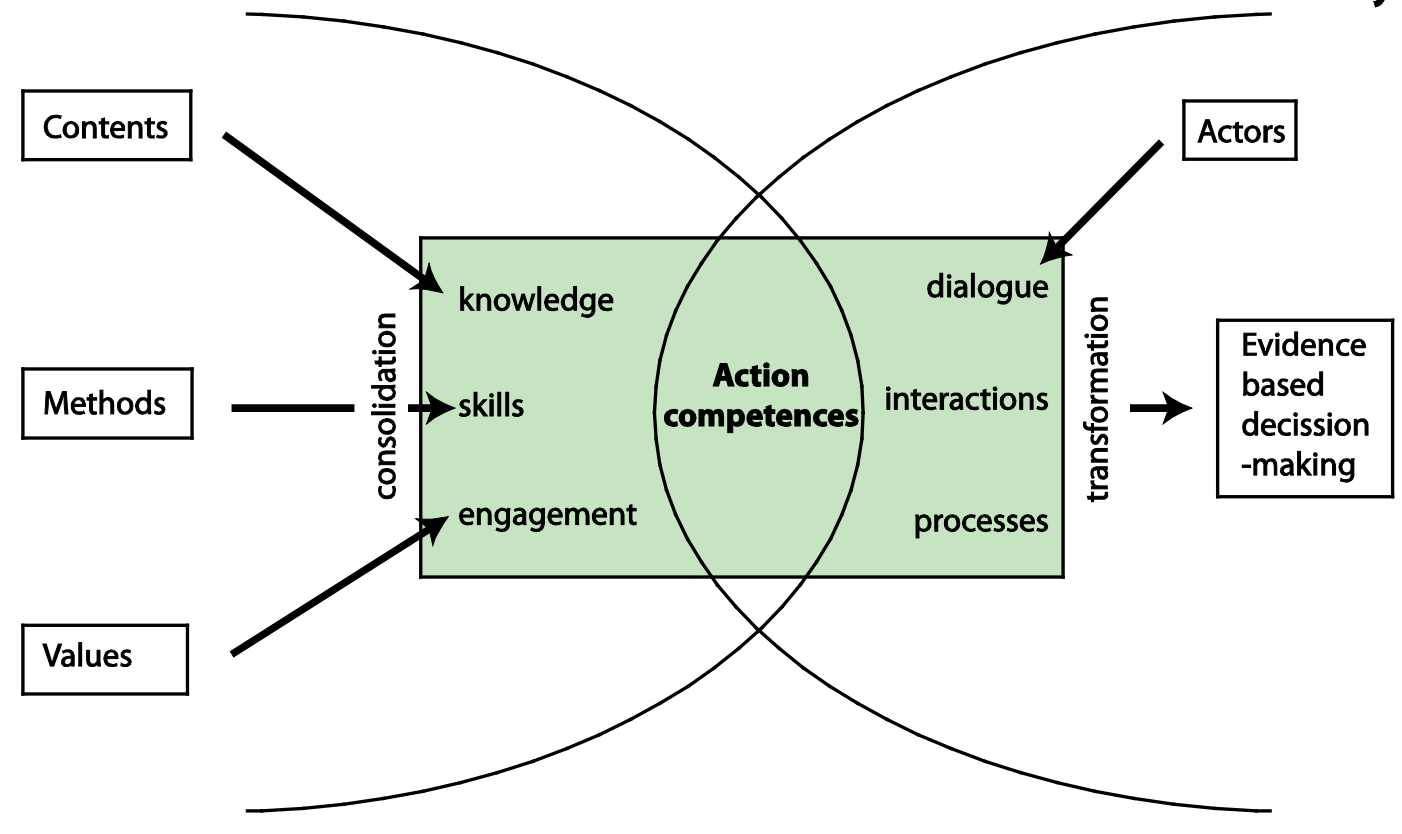

Figure 6. Education-policy interface

However, application of these conclusions in education, that is, translating theoretical principles into concrete curricular changes, is relatively difficult: whilst the development of new genres in science is relatively unlimited, and the scientist's autonomy is relatively great, innovation in education is much more tightly bound to the overall education system and its components (such as the general context and habits, the education "culture", the settings of quality evaluation methods at various levels, etc.), and is related to current education policy (such as the rules and requirements for accrediting study programmes). What is more, the room for education "experiments" - the testing of theoretical principles in educational practice with the objective of implementing innovation - is relatively restricted, at least in the context of the Czech Republic.

Further research needs to heed professional texts used in study and their transformation because these processes reflect changes that are actually underway in communicating knowledge. However, it should deal not only with those texts that have been somehow recognised as "education authorities" (expert books, textbooks, etc.), but also those that students really use and that serve, for example, for interdisciplinary communication (Wikipedia). Also the content and form of scientific messages intended for communication with politicians should be examined: at this interface, texts are produced that are directly grounded in the latest knowledge, but simultaneously provide a selection of the most important information for the given target group (all the summaries for policymakers made with the objective of highlighting the alarming state of the world, such as the aforementioned yearbooks of environmental problems (UNESCO-SCOPE-UNEP, 2011; UNEP, 2012)). The nature of such texts reflects their purpose and objective: to be an intermediary 
in the dialogue between different "worlds"; the transformation of the genre is therefore probably most visible in them. On the other hand, for desirable (but as yet not widespread) practical utilisation of these genres in education and for awareness raising, work with the text of this kind should enable reverse progress: the path to deeper, more complex knowledge by following accompanying references in an area that appears to be promising, for example, from a strategic point of view.

\section{Acknowledgments}

This study was supported by the project GA14-36005S of the Grant Agency CR. Many thanks to those who worked on the English version of the text: Petr Kurfürst, Andrew Barton and Laura Macháčková-Henderson.

\section{References}

- Aarhus Convention 1998.UNECE Convention on Access to Information, Public Participation in Decision-making and Access to J ustice in Environmental Matters (1998). Retrieved from http://www.unece.org/env/pp/treatytext.html

- Adomßent, M. (2013). Exploring universities' transformative potential for sustainability-bound learning in changing landscapes of knowledge communication. J ournal of Cleaner Production, 49(15), 11-24. Retrieved from http://linkinghub.elsevier.com/retrieve/pii/S095965261200443X http://dx.doi.org/10.1016/j.jclepro.2012.08.021

- Allen, J., Ramaekers, G., \& van_der, V. R. (2005) Measuring Competencies of Higher Education Graduates. In D. J. Weerts \& J. Vidal (Eds.), Enhancing Alumni Research: European and American Perspectives, New Directions for Institutional Research, no. 126 (pp. 49-59). San Francisco: Jossey-Bass.

- Adresáře vysokých škol.[online] (2013). Amos. Retrieved from http://www.vysokeskoly.com

- Anderson, L., \& Krathwohl, D. A. (2001). Taxonomy for Learning, Teaching and Assessing: A Revision of Bloom's Taxonomy of Educational Objectives. New York: Longman.

- Bertalanffy, L. (1950). An Outline of General System Theory. Br J Philos Sci, I(2), 134-165. Retrieved from http://bjps.oxfordjournals.org/cgi/doi/10.1093/bjps/I.2.134 http://dx.doi.org/10.1093/bjps/I.2.134

- Böhme, G., W Van_den Daele, Hohlfeld, R., Krohn, W., \& Schäfer, W. (1983). Finalization in Science: The Social Orientation of Scientific Progress. Dordrecht, D. Reidel: Springer.

- Butcher, N. (2011). A Basic Guide to Open Educational Resources (OER). Vancouver, Paris: UNESCO. 
- Cobb, P., \& Bowers, J. (1999). Cognitive and Situated Learning Perspectives in Theory and Practice. Educational Researcher, 28(2), 4-15. Retrieved from http://edr.sagepub.com/cgi/doi/10.3102/0013189X028002004 http://dx.doi.org/10.3102/0013189X028002004

- Čada, K., \& Ptáčková, K. (2013). Possibilities and limits of collaboration between science and NGOs in the Czech Republic. Journal of Cleaner Production, 49(15), 25-34. Retrieved from http://linkinghub.elsevier.com/retrieve/pii/S0959652612003770 http://dx.doi.org/10.1016/j.jclepro.2012.07.039

- Činčera, J. (2009). Výstupy či procesy: paradigmatický (kvazi)spor environmentální výchovy. Envigogika, 4(2), Retrieved from http://www.envigogika.cuni.cz/index.php/Envigogika/article/view/38 http://dx.doi.org/10.14712/18023061.38

- Činčera, J. (2010). Metodika evaluace programů environmentální výchovy. Envigogika, 5(3), Retrieved from http://www.envigogika.cuni.cz/index.php/Envigogika/article/view/149 http://dx.doi.org/10.14712/18023061.149

- Delors, J. ed., (1997). Učení je skryté bohatství (formulovala Mezinárodní komise UNESCO Vzdělávání pro 21. století). Praha: UIV.

- Daniš, P. (2013). A new definition of environmental literacy and a proposal for its international assessment in PISA 2015. Envigogika, 8(4), Retrieved from http://www.envigogika.cuni.cz/index.php/Envigogika/article/view/419 http://dx.doi.org/10.14712/18023061.419

- Dlouhá, J., Dlouhý, J., \& Mezřický, V. (2006). Globalizace a globální problémy. Sborník textů k celouniverzitnímu kurzu 2005-2007. Praha: Univerzita Karlova v Praze, COŽP.

- Dlouhá, J. (2007a) Ekologická etika pro environmentální vzdělávání. In P. Nováček (Ed.), Udržitelný rozvoj. Nové trendy a výzvy. Sborník mezinárodní konference (pp. 71-96). Olomouc: PřF UP.

- Dlouhá, J. (2007b) Environmetnal Literacy in Theory and Practice. EnviWiki - the Czech multimedia Toolkit. In . Hytönen (Ed.), Education for Democracy as a Part of Education for Sustainable Development (pp. 17-30). Helsinki: University of Helsinki.

- Dlouhá, J. (2009a). Obecné vzdělávací kvality a pojem kompetence. Envigogika, 4(1), Retrieved from http://www.envigogika.cuni.cz/index.php/Envigogika/article/view/35 http://dx.doi.org/10.14712/18023061.35

- Dlouhá, J. (2009b). Kompetence v environmentálním vzdělání. Envigogika, 4(1), Retrieved from http://www.envigogika.cuni.cz/index.php/Envigogika/article/view/34 http://dx.doi.org/10.14712/18023061.34 
- Dlouhá J . (2009c). Vědění a participace. Teoretická východiska environmentálního vzdělání. Praha: Karolinum.

- Dlouhá, J., Dlouhý, J., \& Zahradník, M. (2011a) Procesy a př́stupy k učení hodnocení práce studentů ve wiki prostředí. In P. Sojka - M. Kvizda (Ed.), Sborník 7. ročníku konference o elektronické podpoře výuky SCO 2011, Brno, Masarykova univerzita (pp. 75-80). 2011, Brno.

- Dlouhá, J., Činčera, J., Jančaříková, K., Dlouhý, J., \& Scholleová, H. (2011b). Metodika týmové spolupráce a tvorby týmů pro vysokoškolské vzděláván. Envigogika, 6(1), Retrieved from http://www.envigogika.cuni.cz/index.php/Envigogika/article/view/150 http://dx.doi.org/10.14712/18023061.150

- Dlouhá, J., Zahradník, M., Dlouhý, J., \& Barton, A. (2011c) Tools for Evaluating Students? Work in an Interactive (Open) Virtual Space: Case Study of an Elearning Course in an International Network of Universities. In Proceedings of the 10th European Conference on E-learning. Vols 1 and 2 (pp. 166-176). Proceedings of the 10th European Conference on E-learning, Vols 1 And 2 Pages: 166-176.

- Dlouhá, J. (2012) Nové pohledy na vědu v kontextu řešení praktických problémů udržitelného rozvoje - jde o změny paradigmatické nebo jen zbožná přán. In J. Vávra - M. Lapka (Ed.), Měnící se společnost? Varia, Praha, Filosofická fakulta UK v Praze (pp. 56-67). .

- Dlouhá, J. a kol., (2013). Metodika tvorby textů v otevřeném internetovém prostoru. . Retrieved from

http://www.enviwiki.cz/wiki/Metodika_tvorby_text\%C5\%AF_v_otev\%C5\%9 9en\%C3\%A9m_internetov\%C3\%A9m_prostoru

- Dlouhá, J., Huisingh, D., \& Barton, A. (2013). Learning networks in higher education: Universities in search of making effective regional impacts. Journal of Cleaner Production, 49(15), 5-10. Retrieved from http://linkinghub.elsevier.com/retrieve/pii/S0959652613000395 http://dx.doi.org/10.1016/j.jclepro.2013.01.034

- Dlouhá, J., Barton, A., Huisingh, D., \& Adomssent, M. (2013). Learning for sustainable development in regional networks. Journal of Cleaner Production, 49(15), 1-4. Retrieved from http://linkinghub.elsevier.com/retrieve/pii/S0959652613000462 http://dx.doi.org/10.1016/j.jclepro.2013.01.041

- Dlouhá, J., Barton, A., Janoušková, S., \& Dlouhý, J. (2013). Social learning indicators in sustainability-oriented regional learning networks. Journal of Cleaner Production, 49(15), 64-73. Retrieved from http://linkinghub.elsevier.com/retrieve/pii/S0959652612003617 http://dx.doi.org/10.1016/j.jclepro.2012.07.023

- Dlouhá, J., Macháčková-Henderson, L., \& Dlouhý, J. (2013). Learning networks with involvement of higher education institutions. Journal of Cleaner Production, 49(15), 95-104. Retrieved from 
http://linkinghub.elsevier.com/retrieve/pii/S0959652612003034 http://dx.doi.org/10.1016/j.jclepro.2012.06.009

- Dlouhá, J. (2013). Nápověda: Př́padová studie. Enviwiki. . Retrieved from http://www.enviwiki.cz/w/index.php?title=N\%C3\%A1pov\%C4\%9Bda:P\%C5 \%99\%C3\%AADpado\%C3\%A1_studie\&oldid=12604

- Dlouhá, J. (2013) Rubric for assessment of the text. In VCSEWiki. . Retrieved from http://vcsewiki.czp.cuni.cz/w/index.php?title=Rubric_for_assessment_of the $\underline{\text { text\&oldid }=3327}$

- Dlouhá, M. (2011). Autorita ve virtuálním vzdělávání. Envigogika, 6(2), Retrieved from http://www.envigogika.cuni.cz/index.php/Envigogika/article/view/60 http://dx.doi.org/10.14712/18023061.60

- Duff, A. (2003). Quality of Learning on an MBA Programme: The Impact of Approaches to Learning on Academic Performance. Educational Psychology, 23(2), 123-139. Retrieved from http://www.tandfonline.com/doi/abs/10.1080/01443410303230 http://dx.doi.org/10.1080/01443410303230

- Duff, A. (2004). The Revised Approaches to Studying Inventory (RASI) and its Use in Management Education. Active learning in Higher education, 56(5), 57.

- Edquist, C. (1997). Systems of Innovation: Technologies. Institutions and Organisations. New York, London: Pinter publishers.

- Entwistle, N., Tait, H., \& McCune, V. (2000). Patterns of response to an approaches to studying inventory across contrasting groups and contexts. Eur J Psychol Educ, 15(1), 33-48. Retrieved from http://link.springer.com/10.1007/BF03173165 http://dx.doi.org/10.1007/BF03173165

- ETL Project 2013. Learning and Studying Questionnaire (LSQ) Experiences of Teaching and Learning Questionnaire (ETLQ). (2011). . Retrieved from http://www.etl.tla.ed.ac.uk/questionnaires/scoringkey.pdf

- Foucault, M. (2002). Archeologie vědění. 1. vyd. Praha: Herrmann \& synové.

- Etzkowitz, H., \& Leydesdorff, L. (1998). The endless transition: A "triple helix" of university - industry-government relations. Minerva, 36, 203-208.

- Funtowicz, S. O., \& Ravetz, J. R. (1993). Science for the post-normal age. Futures, 25(7), 739-755. Retrieved from http://linkinghub.elsevier.com/retrieve/pii/001632879390022L http://dx.doi.org/10.1016/0016-3287(93)90022-L

- Funtowicz, S. O., \& Ravetz, J. R. (2002). Post-Normal Science - Environmental Policy under Conditions of Complexity. [online] [cit. . Retrieved from http://www.nusap.net 
- Gibbons, M., Limoges, C., Nowotny, H., Schwartzman, S., Scott, P., \& Trow, M. (1994). The New Production of Knowledge: The Dynamics of Science and Research in Contemporary Societies. London: Sage.

- Glennie, J., Harley, K., Butcher, N., \& eds, v. T. (2012). Open Educational Resources and Change in Higher Education: Reflections from Practice. Vancouver, Commonwealth of Learning a UNESCO. .

- Havel, I. (2005) Interdisciplinarita, transdisciplinarita a vysokoškolské vzdělávání. In. In In, \& J. Dlouhá - J. Dlouhý eds., Co (Eds.), Co znamená udržitelnost pro univerzity? Sborník mezinárodní konference, Praha, Univerzita Karlova v Praze, Centrum pro otázky životního prostředí, 15-27, Retrieved from (pp. 15-27). Praha: Univerzita Karlova v Praze, Centrum pro otázky životního prostředí. Retrieved from http://www.czp.cuni.cz/knihovna/konf0509/sbornik.pdf

- Hessels, L. K., \& van Lente, H. (2008). Re-thinking new knowledge production: A literature review and a research agenda. Research Policy, 37(4), 740-760.

Retrieved from http://linkinghub.elsevier.com/retrieve/pii/S0048733308000243 http://dx.doi.org/10.1016/j.respol.2008.01.008

- Huisingh, D. (2006). New challenges in education for sustainable development. Clean Technologies and Environmental Policy, 8(1), 3-8. Retrieved from http://link.springer.com/10.1007/s10098-006-0034-y http://dx.doi.org/10.1007/s10098-006-0034-y

- Kapitulčinová, D., Barton, A., Dlouhá, J., \& Dlouhý, J. (2013) Open Educational Resources. In Enviwiki. . Retrieved from http://enviwiki.cz/w/index.php?title=Open_Educational_Resources\&oldid=12 $\underline{603}$

- Keulartz, J. (1998). Struggle for Nature. A Critique of Radical Ecology. London a. New York: Routledge.

- Keulartz, J. (2009) Boundary-work, Pluralism and the Environment. In J.K.B. Olsen - S.A. Pedersen - V.F. Hendricks (Ed.), A Companion to the Philosophy of Technology (pp. 263-269). Malden: Wiley-Blackwell.

- Komenský, J. A. (1948). Vševýchova Pampaedia. Praha: tátní nakladatelství v Praze.

- Krajhanzl, J. (2009) Ekopsychologie a environmentální chování. In Dlouhá, J. a kol. (Ed.), Vědění a participace. Teoretická východiska environmentálního vzdělání ( $p p$. 132-142). Praha: Karolinum.

- Kvasničková, D. (1990). Závěrečná zpráva hlavního rezortního výzkumu školství RS IX „Ekologické aspekty ve vzdělávání a výchově". .

- Máchal, A. (2007). Průvodce praktickou ekologickou výchovou. Brno: Rezekvítek.

- Mochizuki, Y., \& Fadeeva, Z. (2008). Regional Centres of Expertise on Education for Sustainable Development (RCEs): an overview. International J ournal of Sustainability in Higher Education, 9(4), 369-381. Retrieved from 
http://www.emeraldinsight.com/10.1108/14676370810905490 http://dx.doi.org/10.1108/14676370810905490

- Průcha, J., Walterová, E., \& Mareš, J. (1995). Pedagogický slovník. : Praha, Portál.

- Reeves, T. C. (2006). How do you know they are learning? The importance of alignment in higher education. International J ournal of Learning Technology, 2(4), 294-309. Retrieved from http://www.inderscience.com/link.php?id=11336 http://dx.doi.org/10.1504/IJLT.2006.011336

- Richardson, J. T. E. (2005). Students' perceptions of academic quality and approaches to studying in distance education. British Educational Research J ournal, 31(1), 7-27. Retrieved from http://doi.wiley.com/10.1080/0141192052000310001 http://dx.doi.org/10.1080/0141192052000310001

- Rode, H., \& Michelsen, G. (2008). Levels of Indicator Development for Education for Sustainable Development. Environmental Education Research, 14(1), 19-33. Retrieved from http://www.tandfonline.com/doi/abs/10.1080/13504620701843327 http://dx.doi.org/10.1080/13504620701843327

- Sadler, R. D. (2005). Interpretations of criteria-based assessment and grading in higher education. Assessment \& Evaluation in Higher Education, 30(2), 175-194. Retrieved from http://www.tandfonline.com/doi/abs/10.1080/0260293042000264262 http://dx.doi.org/10.1080/0260293042000264262

- Schneckenberg, D., \& Wildt, J . (2006) Understanding the Concept of eCompetence for Academic Staff. In I. Mac Labhrainn, L. C. McDonald, D. Schneckenberg, \& J. Wildt (Eds.), The Challenge of eCompetence in Academic Staff Development (pp. 29-35). Galway: NUI Galway. Retrieved from http://www.ecompetence.info/uploads/media/ch3.pdf

- Schön, D. (1983). The Reflective Practitioner. How professionals think in action. London, Temple: Smith.

- Smolíková, D. (2006). Věŕím v teorii kapající vody. Rozhovor s Danuší Kvasničkovou. Sedmá generace, 6 , Retrieved from http://www.sedmagenerace.cz/text/detail/verim-v-teorii-kapajici-vody

- Star, S. L., \& Griesemer, J. R. (1989). Institutional Ecology, 'Translations' and Boundary Objects: Amateurs and Professionals in Berkeley's Museum of Vertebrate Zoology, 1907-39. Social Studies of Science, 19(3), 387-420. Retrieved from http://sss.sagepub.com/cgi/doi/10.1177/030631289019003001 http://dx.doi.org/10.1177/030631289019003001

- Sterling, S. (1996) Education in Change. In J. Huckle - S. Sterling eds (Ed.), Education for Sustainability. London: Earthscan Publications Ltd.. 
- Štech, S. (1999) Teoretické přístupy k vysokoškolské pedagogice. In J. Vašutová (Ed.), Vybrané otázky vysokoškolské pedagogiky (pp. 157-166). Praha: ÚVRŠ.

- Tilbury, D. (2004) Environmental education for sustainability: A force for change in higher education. In P. B. Corcoran \& A. E. J. Wals (Eds.), Higher education and the challenge of sustainability (pp. 97-112). London: Kluwer Academic Publishers.

- Tilbury, D. (2011). Education for Sustainable Development. An Expert Review of Processes and Learning. Paris: UNESCO, Section for Education for Sustainable Development.

- Tillbury, D. Ed., (2012). Peoples' Sustainability Treaty on Higher Education. Draft for Rio+20. . Retrieved from http://sustainabilitytreaties.org/drafttreaties/higher-education

- UN, (1992). Agenda 21. United Nations Conference on Evironment \& Development, Rio de Janerio, Brazil, 3 to 14 J une 1992. . Retrieved from http://sustainabledevelopment.un.org/content/documents/Agenda21.pdf

- UNECE, (2009). Learning from each other The UNECE Strategy for Education for Sustainable Development. . Retrieved from

http://www.unece.org/env/esd/Implementation/Publication/LearningFromEach Other.pdf

- UNECE, (2011). Learning for the future: Competences in Education for Sustainable Development. Geneva, United Nations Economic Commission for Europe, Steering Committee on Education for Sustainable Development. . Retrieved from http://www.unece.org/fileadmin/DAM/env/esd/ESD_Publications/Competenc es_Publication.pdf

- UNECE, (2013). Empowering educators for a sustainable future: Tools for policy and practice workshops on education for sustainable development Competences. : Geneva, United Nations Economic Commission for Europe, Steering Committee on Education for Sustainable Development.

- UNEP, (2012). UNEP Year Book: Emerging issues in our global environment. Nairobi, UNEP. Retrieved from http://www.unep.org/yearbook/2012

- UNESCO, (2005). Toward knowledge societies. UNESCO World Report. Conde-surNoireau: United Nations Educational, Scientific and Cultural Organization.

- UNESCO-SCOPE-UNEP 2011. Policy Brief No. 14 - Engineering the Climate: Research questions and policy implications . . Retrieved from http://www.scopenvironment.org/unesco/USUPB14\%20Geoengineering\%20a150.pdf

- UNI IAS 2013. Regional Centres of Expertise . Retrieved from https://www.ias.unu.edu/sub_page.aspx?catID=1849\&ddlID=183

- Wals, A. E. J. (ed.), (2007). Social Learning Towards a Sustainable World. Wageningen: Wageningen Academic Publishers. 
- Wals, A. E., Brody, M., Dillon, J., \& Stevenson, R. B. (2014). Convergence Between Science and Environmental Education. Convergence Between Science and Environmental Education. Science, 344(6184), 583-584. Retrieved from http://www.sciencemag.org/cgi/doi/10.1126/science.1250515 http://dx.doi.org/10.1126/science.1250515

- Weinert, F. E. (2001) Defining and selecting key competences. Concept of Competence. A Conceptual Clarification. In D.S. Rychen - L.H. Salganik (Ed.), Defining and selecting key competencies. Cambridge (State of Washington) a Göttingen: Hogrefe \& Huber.

- Wiek, A., Withycombe, L., \& Redman, C. L. (2011). Key competencies in sustainability: a reference framework for academic program development. Sustainability Science, 6(2), 203-218. Retrieved from http://link.springer.com/10.1007/s11625-011-0132-6 http://dx.doi.org/10.1007/s11625-011-0132-6

- Zilahy, G., \& Huisingh, D. (2009). The roles of academia in Regional Sustainability Initiatives. J ournal of Cleaner Production, 17(12), 1057-1066. Retrieved from http://linkinghub.elsevier.com/retrieve/pii/S095965260900105X http://dx.doi.org/10.1016/j.jclepro.2009.03.018

- Zahradník, M., \& Pachmanová, L. (2009). Příklad využití wiki-prostředí v environmentálním vzdělávání na vysoké škole: hodnocení kurzu Organizace a řízení ochrany životního prostředí. Envigogika, 4(3), Retrieved from http://www. envigogika.cuni.cz/index.php/Envigogika/article/view/46 http://dx.doi.org/10.14712/18023061.46

- Ziman, J. (2000). Real Science: What it is, and What it Means. Cambridge, Cambridge: Cambridge University Press. Retrieved from http://ebooks.cambridge.org/ref/id/CBO9780511541391 http://dx.doi.org/10.1017/CBO9780511541391

Jana Dlouhá

Charles University Environment Centre, Department of Environmental Education.

The author is concerned with innovative processes in higher education for sustainable development (in practice) and their reflection (in theory). She is chief editor of the Envigogika journal.

\section{e-mail: jana.dlouha@czp.cuni.cz}

\section{Jiří Dlouhý}

Charles University Environment Centre, Department of Environmental Education; Society for Sustainable Living

Jiři Dlouhý is head of Department of Environmental Education and president of Society for Sustainable Living. He is main editor of Enviwiki resource base.

e-mail: jiri.dlouhy@czp.cuni.cz 